\title{
Islam, Etika Dan Spiritualitas: Perannya Dalam Dunia Konseling Dan Keperawatan yang Multikultur
}

\author{
Zakiyah Isnawati \\ IAIN Kudus, Jawa Tengah, Indonesia \\ zakiyahisnawati79@gmail.com
}

\begin{abstract}
Abstrak
Dunia profesi keperawatan dan konseling merupakan kegiatan yang banyak menggunakan komunikasi dan tatap muka antar manusia. Objek dan subjek yang berkomunikasi bisa saja memiliki perbedaan -perbedaan yang mendasar seperti ras, budaya, agama, dan lain-lain. Tulisan ini menekankan pada aspek spiritualitas dan etika, khususnya dalam ajaran agama Islam dalam memecahkan permasalahan multikultural dan perbedaan di dunia keperawatan dan konseling. Islam sebagai agama dengan pemeluk yang besar di dunia ini pastinya diikuti oleh tumbuhnya budaya di masing-masing wilayah. Tujuan tulisan ini adalah untuk menemukan relevansi ajaran Islam dalam dunia keperawatan dan konseling, khususnya aspek spiritualitas dan etis.
\end{abstract}

Kata kunci: Islam, Keperawatan dan konseling, Spiritualitas, Etika, Multikultur

\begin{abstract}
The world of nursing and counseling is an activity that uses a lot of communication and face to face between people. Objects and subjects that communicate may have fundamental differences such as race, culture, religion, etc. This paper emphasizes aspects of spirituality and ethics, especially in Islamic teachings in solving multicultural problems and differences in the world of nursing and counseling. Islam as a religion with a large adherent in the world is certainly followed by the growth of culture in each region. The purpose of this paper is to find the relevance of Islamic teachings in
\end{abstract}


the world of nursing and counseling, especially aspects of spirituality and ethics.

Keywords: Islam, nursing and counseling, spirituality, ethics, multicultural

\section{A. Pendahuluan}

Kelemahan psikolog dengan paradigma Barat ialah kurangnya menilik psikologi lokal/indigenous/alternatif. Oleh karena itu mereka cenderung memperlakukan masyarakat sebagai variabel independen dan memeriksa efek dari variabel-variabel tersebut pada fenomena psikologis yang relevan. Seperti semua disiplin ilmu, psikologi lintas budaya juga dipandu oleh beberapa asumsi yang saling terkait. Salah satu yang harus kita pegang adalah keyakinan dalam variasi budaya (Stephen Palmer, 1999).

Dalam mengenali metode konseling yang kultural-tradisional dan alternatif, konseling-konseling yang eurosentris dan individualistis akan ditantang dan diubah. Konseling multikultural yang dialami dengan cara ini juga akan menantang epistemologi yang ada serta menginformasikan konseling dan terapi (Roy Moodley, 1999). Begitupun ketika membicarakan kultur agama dalam konseling dan keperawatan, khususnya agama Islam yang erat kaitannya dengan keimanan. Karena nilai-nilai dasar dan keyakinan sering berakar pada keimanan dan praktik agama, mereka sangat menyebar dan memandu perilaku baik pasien maupun klinisi. Salah satu perhatian utama ketika memasukkan isu-isu spiritual atau agama ke dalam praktik klinis adalah meningkatnya keragaman budaya dengan keragaman keyakinan dan praktik spiritual serta agama yang menyertainya (Rebecca \& Joan, 2012).

Keragaman budaya ini kemudian dapat dilakukan dengan cara menemukan kecocokan antara konselor dan klien juga penuh dengan kesulitan praktis, paling tidak adalah kurangnya jumlah konselor dari kelompok etnis minoritas. Sementara mempekerjakan konselor yang cocok secara etnis dapat membuat layanan lebih menarik bagi kelompok etnis tertentu, praktisi konseling dari latar belakang ras dan etnis yang berbeda tidak dapat terwakili secara keseluruhan. Meluruskan ketidakseimbangan permintaan dan kebutuhan seperti itu akan membutuhkan tekad dan komitmen yang 
besar dari mereka yang memiliki pengaruh dalam perekrutan dan pelatihan praktisi ke dalam badan profesional. Masalah ini perlu ditangani di tingkat masyarakat (misalnya, melalui badan-badan profesional) (Stephen Palmer, dkk, 1999).

\section{B. Pembahasan}

\section{Islam dalam Bingkai Etika dan Spiritualitas}

Banyak tradisi spiritual termasuk pengembangan sikap welas asih dan pemberlakuan perilaku welas asih sebagai elemen eksplisit (terbuka). Dengan penonjolan sikap welas asih dalam tradisi spiritual yang beragam, ada kemungkinan bahwa individu-individu yang memiliki rasa spiritualitas yang kuat mungkin lebih cenderung untuk mengemban sikap dan keyakinan penuh kasih ke dalam proses psikologis mereka. Dengan demikian, masuk akal bahwa rasa spiritualitas akan berhubungan positif dengan rasa sayang pada diri sendiri (Jacob K. Farnsworth, dkk, 2016).

Salah satu tradisi spiritual itu sangat lekat dengan pandangan agama Islam dan para pemeluknya (Muslim). Umat Muslim percaya pada silsilah Nabi yang dimulai dengan Nabi Adam dan berakhir dengan Nabi Muhammad (SAW). Ajaran fundamental Islam yang paling penting adalah keimanan akan keesaan Tuhan - ini disebut Tauhid. Ini dijelaskan dalam Syahadah, unsur pertama dari iman: 'Saya bersaksi bahwa tidak ada Tuhan selain Allah dan saya bersaksi bahwa Muhammad adalah hamba dan utusanNya'. Faktanya, tidak ada seorangpun yang layak disembah kecuali Allah. Kerangka model gaya hidup dan praktik Muslim adalah: syahadah, sholat, Zakat, puasa (Ramadhan) dan ziarah (Haji) ke Mekkah.

\section{a. Syahadah}

Tidak ada tuhan selain Allah dan Muhammad (SAW) adalah utusan-Nya. Deklarasi ini adalah artikel pertama dari iman yang disebut Syahadah.

\section{b. Sholat}

Ada sholat wajib yang dilakukan lima kali sehari pada waktu yang ditentukan. Ini adalah hubungan langsung antara penyembah (hamba) dan Allah. 


\section{c. Zakat}

Kata Zakat berarti pemurnian dan pertumbuhan. Harta kita yakni merupakan tanggungjawab oleh manusia didalam keimanan, harta tersebut dimurnikan dengan menyisihkan sebagian untuk mereka yang membutuhkan. Setiap Muslim menghitung zakatnya masing-masing dan melibatkan pembayaran setiap tahun dari harta mereka dan diberikan kepada yang membutuhkan dan yang miskin. Ini memberikan pedoman untuk penyediaan keadilan sosial, perilaku manusia yang positif dan menumbuhkan sistem sosio-ekonomi yang adil. Salah satu hadits (mengatakan) Nabi Muhammad (SAW) yang berkaitan dengan amal adalah bahwa 'Kekayaan hamba tidak pernah berkurang dengan membayar amal'.

\section{d. Puasa}

Setiap tahun selama bulan Ramadhan, umat Islam berpuasa sejak terbitnya matahari sampai matahari terbenam dengan cara menjauhkan diri dari makan, minum dan hubungan seksual. Meskipun puasa bermanfaat untuk kesehatan, secara spiritual dianggap sebagai metode pemurnian diri. Dimensi spiritual melibatkan praktik reflektif, meningkatkan doa, dan memiliki pemikiran positif terhadap orang lain serta mengingat Allah dalam pikiran serta tindakan.

\section{e. Ziarah (Haji)}

Ziarah tahunan Haji di Mekah, Kerajaan Arab Saudi adalah kewajiban bagi semua Muslim sekali seumur hidup. Namun, ada beberapa kondisi seperti hanya orang-orang yang mampu secara fisik dan finansial yang dapat melakukannya. Ritual haji berlangsung pada bulan ke-12 tahun Islam (berdasarkan sistem Bulan, Tahun Islam 1420/1421 H/ CE 2000). Para peziarah mengenakan pakaian sederhana, yang bermakna melepaskan diri dari nafsu, status, perbedaan kelas, budaya dan warna kulit, sehingga semua individu dihadapan Allah sama derajatnya (Rassool G.H., 2000).

Teologi penghormatan termaktub dalam banyak ayat Alquran dan menyebutkan bahwa "Manusia adalah mahluk yang dihormati dan memiliki status terhormat dalam Islam". Allah berfirman:' Dan sesungguhnya Kami telah menghormati Anak-Anak Adam, dan Kami telah membawa mereka di darat dan laut, dan telah 
memberi mereka hal-hal baik yang sah, dan lebih memilih mereka di atas banyak dari mereka yang telah Kami ciptakan dengan pilihan yang ditandai"'(Al-Israa': 70); "Muhammad adalah utusan Allah. Dan orang-orang yang bersamanya adalah keras terhadap orang-orang kafir, dan berbelas kasihan di antara mereka sendiri" (Al-Fath: 29); "Kemudian dia menjadi salah satu dari mereka yang percaya (dalam Islam Monotheisme) dan merekomendasikan satu sama lain untuk ketekunan dan kesabaran, dan (juga) merekomendasikan satu sama lain untuk belas kasihan dan belas kasih. Mereka adalah orang-orang di Tangan Kanan (penghuni surga)" (Al-Balad: 17-18) (Nazila, 2011).

Nabi Muhammad menggambarkan orang-orang yang beriman seperti satu tubuh. Nabi berkata: "Kesamaan orang-orang yang percaya dalam cinta, belas kasih, ibarat tubuh; jika satu bagian darinya sakit, maka semuanya akan merasakan sakit". Menghormati orang tua dan menghormati mereka adalah karakteristik masyarakat Muslim. Nabi Muhammad berkata: "Bagian dari memuliakan Allah adalah menghormati Muslim yang sudah berambut abu-abu (tua)" (Abu Dawud). Nabi juga mengatakan: "Tidak ada satupun dari kalian yang benar-benar percaya sampai dia mencintai saudaranya apa yang dia cintai untuk dirinya sendiri (Al-Bukhari). Dia juga berkata:" Yang Maha Penyayang memiliki belas kasihan pada mereka yang berbelas kasihan. Berbelaskasihanlah kepada mereka yang ada di bumi agar Yang Di surga akan mengasihimu "(At-Tirmidhi) (Nazila, 2011).

Etika pengasuhan spiritual Islam adalah sama dengan prinsip-prinsip hak asasi manusia - kasih sayang, keadilan sosial, kesetaraan dan perlakuan yang setara - dalam hal ini mereka membimbing interaksi antara perawat dengan pasien (Nazila, 2011). Adapun cara yang ditempuh ialah: Pertama, menggunakan dan menerampak Alquran dan Sunnah yang merupakan dua sumber fundamental Islam. Umat Muslim menerima Alquran sebagai sumber bimbingan dan inspirasi dari firman Allah yang tidak berubah sejak wahyu itu turun. Umat Muslim juga menerimanya sebagai sumber penyembuhan, obat untuk penyakit dan sumber kenyamanan serta kedamaian. Alquran selalu diperlakukan dengan penuh hormat di kalangan umat Islam, yang biasanya mengambil wudhu sebelum menyentuh dan membaca Alquran. 
Kedua, ayat-ayat Alquran dan tradisi kenabian menekankan pendekatan manusiawi dan ilmiah terhadap penyakit. Alquran secara positif mempengaruhi sikap sosial terhadap orang sakit. Ketiga, Sunnah selalu diperlakukan sebagai sumber penting untuk memahami Alquran karena Nabi memberikan demonstrasi dalam praktisnya. Dia (Nabi Muhammad) adalah Alquran yang hidup, yang melaksanakan cita-cita dan nilai-nilainya. Muslim tidak hanya membaca Hadis, tetapi juga harus mempelajarinya dan mengikuti ajaran kenabian.

Keempat, ketika Nabi menunjukkan rincian bagaimana melakukan sholat lima waktu, puasa pada bulan Ramadhan, melaksanakan haji (ziarah) dan membayar zakat (sedekah), ia juga merupakan model sempurna pengasuh spiritual dan religius. Kemudian, mereka menganggapnya sebagai kewajiban untuk mengikuti akhlak dan karakteristik Nabi. Kelima, Alquran juga menekankan bahwa umat Islam harus mengikuti Nabi sebagai model mereka: "Dan sesungguhnya di dalam utusan Allah kamu memiliki contoh yang baik untuk dia yang bertakwa kepada Allah dan hari akhir dan mengingat Allah " (Alquran 33: 31) (Nazila, 2011).

Perlu ditekankan bahwa Islam adalah sistem kepercayaan yang penuh perhatian dan menyeluruh. Belas kasih Allah dan harapan bahwa umat Islam dituntut untuk berbelas kasih dan berbelas kasih kepada orang lain. Sementara Islam jelas menentang alkoholisme, pergaulan seksual atau masalah gaya hidup seperti praktek homoseksual, namun hal itu tidak melarang perawat Muslim dan profesional perawatan kesehatan lainnya dari merawat pasien Muslim dan non-Muslim. Tidak ada perintah larangan dalam penyediaan perawatan untuk pasien Muslim maupun non-Muslim yang mengidap HIV / AIDS atau penyalahgunaan zat adikif. Dibawah ideologi dan praktik Islam, perawat tidak melihat/membedabedakan pada keyakinan penderitanya, atau kelompok etnisnya, atau status sosial atau kekayaannya. Oleh karena itu, ia peduli dan memperlakukan secara sama antara non-Muslim dengan Muslim (Rassool G.H., 2000). 


\section{2. (Institusi) Islam dan Spiritualitas serta Perannya dalam Konseling dan Keperawatan}

Institusi Islam bertanggung jawab atas keperawatan dan pembinaan berbasis spiritual Islam yang efektif. Di masa lalu, institusi Islam merupakan bagian integral dari sistem perawatan kesehatan. Komunitas Muslim memiliki beberapa organisasi besar, termasuk Kongres Islam Kanada, Masyarakat Islam Amerika Utara, Asosiasi Muslim Kanada, Dewan Wanita Muslim Kanada, Dewan Kanada tentang Hubungan Amerika-Islam (CAIR-CAN), North American Muslim Foundation (NAMF), Kongres Muslim Kanada, Persatuan Muslim Kanada, Lingkar Islam Amerika Utara, dan seterusnya, yang kini menjadi organisasi advokasi dan kebebasan sipil terkemuka. Namun, banyak organisasi etno-budaya juga berfungsi sebagai lembaga spiritual dan agama bagi umat Islam di Kanada. Organisasi-organisasi ini bervariasi terlihat dari apa mereka tawarkan dalam hal pembinaan spiritual dan religius, tidak seperti layanan yang ditemukan di masjid, yang didalamnya terdapat komponen kepemimpinan, keanggotaan, elemen etnis, kehadiran di sholat Jum 'ah (ibadah ibadah mingguan utama); sekolah-masjid (ngaji) (kehadiran mingguan, semua usia); gaji (termasuk tunjangan); dan zakat (Nazila, 2011).

Dalam hal ini, pengawasan/pembinaan klinis sangat penting dalam memungkinkan praktisi untuk mengeksplorasi tema-tema lintas budaya lebih lanjut. Pengawasan yang saling mendukung dan suportif harus memfasilitasi pertanyaan konstruktif dari sikap seorang praktisi dan harapan pekerjaan lintas budaya. Kebutuhan pelatihan yang tepat bagi pengawas sama mendesaknya dengan para peserta pelatihan konseling yang baru pertama kali (Stephen Palmer, dkk, 1999). Banyak pembina spiritual Muslim (Imam) mewakili masjid, yang merupakan tempat penting bagi umat Islam. Alquran juga menekankan pentingnya masjid dalam kehidupan Muslim: "Di rumah-rumah, yang Allah telah diizinkan untuk ditinggikan dan bahwa nama-Nya dapat diingat di dalamnya, di sana memuliakan Dia di pagi hari dan malam hari" (Alquran, 24:36). Selain sholat wajib lima waktu, ada shalat Jumat mingguan, yang wajib dan dilaksanakan di masjid. Dalam praktik dan isinya, shalat Jumat adalah seperti 
ibadah lainnya, tetapi karena sejumlah besar orang berkumpul dimana khotbah memberikan bimbingan agama yang dikhotbahkan oleh imam sebelum sholat dimulai. Dalam khotbah ini, imam mengingatkan para penyembah tentang pertanggungjawaban mereka kepada Tuhan, karakteristik seorang Muslim yang baik, dan tingkah laku yang pantas dalam masyarakat. Dengan cara ini, khotbah Jumat menyegarkan ingatan tentang komitmen agama. Bagi umat Muslim, sholat Jumat dan Idul Fitri adalah contoh kuat dari sifat komunitas Muslim dalam kesatuan pendapat dan kesamaan tujuan mereka (Nazila, 2011).

Masjid juga digunakan untuk pertemuan sosial, seperti upacara pernikahan, upacara pemakaman, pengadilan hukum, dan upacara keagamaan lainnya. Sangat menyedihkan untuk dicatat bahwa ada sedikit perubahan mendasar dalam fungsi dasar para imam dan pengasuh spiritual dan religius Muslim lainnya selama satu dekade, dan kadang-kadang kita tidak menyaksikan fleksibilitas dalam menanggapi perubahan yang tidak terduga. Imam harus bertindak sebagai fasilitator aksi sosial. Saat ini, pembinaan spiritual Islam mencakup berbagai fungsi dan administrasi yang mudah diamati oleh orang luar. Biasanya mencakup berbagai fungsi khusus, seperti pengajaran, kelembagaan, pekerjaan dakwah (mengajarkan dan menyebarkan Islam ke non-Muslim), dan seterusnya. Tergantung pada waktu dan situasi, tampaknya akan lebih baik jika pembinaan spiritual Islam terkonsentrasi pada satu bentuk dalam satu waktu (Nazila, 2011).

Ini menunjukkan bahwa unsur agama, dalam konteks ini, iman Islam, diterapkan pada konseling, khususnya aspek akidah, ibadah dan akhlak. Aspek iman yang diterapkan dalam konseling memiliki dampak positif pada klien, dalam penelitian ini seperti memberikan ketenangan pikiran, mendidik mereka untuk menjadi kuat dan tangguh dalam menghadapi masalah kehidupan dan memungkinkan mereka untuk bersikap rasional. Dalam aspek ibadah, klien jelas termotivasi untuk melakukan praktik ibadah tertentu dan melanjutkan hidup. Dalam aspek akhlak, klien juga termotivasi untuk mereformasi karakter mereka menjadi lebih baik. Selain itu, ada juga implikasi pada konselor (orang yang memandu konseling) itu sendiri, di mana mereka semakin didorong untuk 
menerapkan pendekatan Islam dalam konselingnya karena efek positif yang terlihat pada klien (Salasiah \& Noor, 2013).

Leeuwen (2006) dalam penelitiannya terhadap hubungan antara perawat dan spiritualitas mengatakan bahwa, "Perawat menekankan kualitas seperti menunjukkan rasa hormat dan tidak menilai orang-orang yang memiliki pandangan agama yang berbeda. Pendeta rumah sakit percaya bahwa perawat secara alami cenderung mencari solusi. Ini berbeda dengan 'sikap spiritual', yang membutuhkan kualitas lebih reflektif." Pendeta rumah sakit mengatakan, "Perawat harus memiliki sikap yang lebih reflektif, memperhatikan ketidakberdayaan, kesedihan dan kekecewaan pasien (empati). Hal-hal ini dapat dikomunikasikan pada saat pasien sedang dirawat. Perawat sangat fokus untuk mencari solusi: 'kami punya masalah dan kami akan menyelesaikannya'. Ada banyak hal yang bisa diperoleh dari mendengarkan apa yang benar-benar penting bagi pasien".

Lanjut Leeuwen menjelaskan bahwa tampaknya aspek spiritualitas juga terkait dengan emosi tertentu yang ditampilkan oleh perawat. Hal ini menjadi sangat jelas selama wawancara ketika situasi konflik batin disebutkan (bagaimana pasien yang sekarat ini berbicara begitu positif tentang Tuhan?). Perawat mengatakan, "Apa yang selalu saya pelajari adalah pasien yang memiliki pandangan hidup berbeda dari saya. Saya mencoba menerima orang-orang dan menghormati mereka, dan saya melakukan ini. Sisi lain dari itu adalah saya berhadapan dengan diri saya sendiri, karena saya memiliki gagasan berbeda tentang kehidupan. Dalam banyak kasus, perawat tidak akan membahas aspek-aspek ini dengan pasien, tetapi itu mengarah pada refleksi pribadi. Perawat juga menyebutkan situasi dimana mereka hampir tidak bisa menangani beban emosional dan secara pribadi terluka. Hal ini memunculkan pikiran ambivalen karena beberapa perawat mengatakan bahwa emosi ini harus diizinkan, tetapi bertanya-tanya apakah ini benar" (Leeuwen, 2006).

Sedangkan Van Dover L \& Pfeiffer (2007) dalam penelitiannya terhadap perawat Parish Nurses mengatakan, "Mengaktifkan atau memelihara iman 'termasuk jawaban Parish Nurses kepada, dan refleksi atas, kedekatan dengan Tuhan. Ide sentral dari 'kemitraan dengan Tuhan' sekali lagi disoroti. Perawat 
ketergantungan pada, dan memiliki kemitraan dengan Tuhan yang kemudian mengarah kepada 'koneksi' spiritual di mana pasien berpartisipasi. Ini menginformasikan arah perawatan yang mendorong komunikasi lebih lanjut dengan Tuhan dan pasien atau keluarga. Parish Nurses memilih intervensi yang dapat menafsirkan pengalaman pasien dalam konteks iman dan kesehatan. Ide ini menjelaskan bahwa Tuhan yang transenden menginformasikan dan membimbing perawatan spiritual yang diberikan oleh perawat,hal ini adalah unik dalam studi penelitian keperawatan." Disisi lain, konselor juga harus waspada terhadap bahaya sikap pasif atau sikap sinis dari kehidupan dalam menghadapi perbedaan cara pandang. Konselor dapat membantu klien melakukan apa yang dapat dilakukan dan tidak jatuh ke dalam sikap pasif dan rasa puas diri karena seseorang tidak dapat melakukan semua yang dapat dilakukan (Stephen Parker, 2011).

Nazila Isgandarova (2011) dalam penelitiannya mengemukakan bahwa, "Penyedia perawatan spiritual dan religius juga harus menunjukkan belas kasih dan cinta kepada pasien sehingga mereka tidak merasa sendirian di masa rentan dalam hidup mereka. Responden 2 menyebutkan pentingnya lingkungan yang peduli: "Kebebasan beragama adalah yang paling penting. Umat Islam harus diberikan waktu luang untuk melakukan kegiatan doa harian mereka, bahkan jika itu bertentangan dengan pusat kegiatan atau jadwal sendiri." Responden 3 mengatakan bahwa lingkungan yang peduli berarti "menjangkau dengan tangan terbuka, dengan hati yang hangat dan jiwa yang pengertian; kita membuat komitmen untuk berbagi penderitaan mereka. Ketika kita memberikan semangat pada mereka, menawarkan kenyamanan, persahabatan dan hiburan, kita harus membawa rasa keutuhan dan koneksi ke komunitas Muslim yang memperbaiki dan menyembuhkan dunia kita".

Selama pembinaan spiritual dan religius Islam, pengasuh spiritual dan religius Muslim bertemu orang-orang dalam pengaturan sehari-hari. Mereka mencoba menyebarkan kasih Tuhan kepada orang-orang pada nurani terdalam mereka, untuk menghilangkan luka dan kesedihan mereka. Mereka mencoba untuk memenuhi kebutuhan manusia di rumah sakit, penjara, panti jompo, dan sebagainya. Mereka melakukan pembinaan spiritual dan 
keagamaan hampir setiap hari. Mereka mendengarkan orang dengan sabar, mengenal latarbelakang mereka, bersukacita bersama mereka dalam pencapaian mereka dan meneguhkan mereka, mengucapkan beberapa doa pagi, membaca doa-doa suci, dan seterusnya. Saat melakukan semua tugas ini, mereka juga menghadapi masalah etika yang signifikan karena mereka bekerja dengan orang dan mengetahui rahasia sensitif mereka, yang mereka bagikan atau saksikan. Orang-orang ini, terutama mereka yang berada di fasilitas perawatan jangka panjang, lebih rentan dalam kasus ini.

Pembina/guru spiritual, Imam, saat ini diibaratkan seperti Nabi Musa, ditantang untuk menjadi ahli dan seorang pelajar yang mencari kebijaksanaan di luar penderitaan pribadi dan komunitas Muslim. Mereka membutuhkan pelatihan yang dapat memperlengkapi mereka dengan alat dan keterampilan yang mereka butuhkan untuk menjadi efektif dalam pembinaan spiritual dan religius mereka kepada umat Islam. Pembina spiritual dan religius Muslim menerapkan teknik yang berbeda untuk memberikan perawatan yang efektif. Teknik-teknik ini termasuk yang lebih tradisional seperti penafsiran mimpi, pengusiran roh, permohonan doa, dan keterampilan/teknik konseling kontemporer.

Mengambil tradisi Alquran dan Kenabian sebagai pedoman utama, tabib tradisional Muslim melihat penyakit sebagai kesempatan untuk melayani, membersihkan, memurnikan dan menyeimbangkan fisik, emosional, mental dan spiritual. Ketika dokter merawat tubuh, pembina/guru spiritual dan religius terlibat dengan jiwa yang belas kasih. Dalam hal ini, mereka adalah dokter kejiwaan, ahli dalam pasien yang terluka oleh dosa dan oleh masalah mental serta emosional; mereka adalah para profesional yang tahu bagaimana menerapkan ramuan yang ampuh dari Tuhan Yang Maha Pengasih dan menerapkan media sains yang kuat sehingga setiap persoalan dapat dipulihkan.

Temuan penelitian menunjukkan bahwa efektivitas pembinaan spiritual Islam tergantung pada beberapa faktor. Pertama, pendidikan dalam teologi Islam adalah inti dari perawatan spiritual Islam yang efektif. Pembina spiritual Muslim biasanya menerima pelatihan agama Islam secara ketat, yang didasarkan pada studi bahasa Arab, Alquran dan Hadits. Studi ini juga termasuk 
menghafal teks-teks Alquran, Hadits dan fatwa/hukum (pernyataan yuridis). Kedua, ilmu-ilmu sosial merupakan komponen penting dari pembinaan spiritual dan religius Islam. Pelatihan yang memadai bagi pembina spiritual Muslim dapat membantu mereka dalam membantu umat Islam dengan masalah emosional dan keluarga yang tidak dapat ditangani hanya dengan pendekatan teoritis tetapi memerlukan pelatihan praktis dan pengalaman dalam ilmu sosial. Dengan demikian, perlu untuk mengembangkan artikulasi yang jelas tentang hubungan antara ilmu-ilmu sosial, khususnya psikologi dan teologi, dan gaya pembinaan spiritual dan religius Islam yang mempertimbangkan tindakan dan refleksi teologis atas pengalaman. Proses membangun pendekatan integral membutuhkan: (1) peran teologi Islam yang eksplisit atau implisit; (2) hubungan dengan berbagai bidang dan disiplin ilmu diluar ilmu agama atau teologi, terutama ilmu sosial dan perilaku; (3) kesadaran akan pentingnya komunitas Muslim; dan (4) integrasi antara teori dan praksis (Nazila, 2011).

Namun seorang Imam juga tidak boleh bersikap rasis terhadap pasien atau orang yang ia asuh. Pittu Laungani mengatakan, "Orang berpendidikan sering disebut sebagai orang yang berbudaya. Jadi budaya didefinisikan dalam istilah individu yang memiliki sikap dan nilai-nilai tertentu yang diinginkan yang merupakan produk dari pembelajaran dan pendidikan. Tetapi pandangan budaya seperti itu juga mengalami masalah serius karena dengan implikasinya ia mengesampingkan semua orang yang tidak memiliki pembelajaran dan pendidikan formal. Setiap masyarakat, besar atau kecil, maju atau maju, memiliki di dalamnya sekelompok orang (persentase mereka dapat bervariasi dari masyarakat ke masyarakat) yang, untuk satu alasan atau lainnya, belum memiliki pembelajaran dan pendidikan formal. Untuk ini harus ditambahkan beberapa masyarakat berskala kecil yang berada di seluruh dunia dimana orang tidak memiliki pendidikan formal dan pembelajaran. Mengacu pada orang-orang dari masyarakat seperti itu sebagai tidak berbudaya (dengan asumsi tentu saja kata yang tidak berbudaya adalah kebalikan konotatif dari kata yang dibudidayakan) adalah untuk membebani diri sendiri terhadap tuduhan elitisme dan rasisme - tuduhan yang ditujukan kepada antropolog (Stephen Palmer, dkk, 1999). 
Penting untuk menunjukkan bahwa meski bertentangan dengan asumsi umum, pembinaan spiritual dan keagamaan Islam pada dasarnya tidak berada di tangan para imam, yang bergantung pada administrasi masjid. Namun, imam telah menjadi profesional utama di komunitas Muslim untuk memberikan pembinaan spiritual dan melayani sebagai pemimpin masyarakat sejak zaman Nabi. Sumber daya masjid, ruang mereka, pendapatan mereka dari wakaf dan sumbangan yang memberikan dasar untuk kegiatan dan fungsi mereka. Masjid membangun atau mendorong komitmen pemuda setempat dan anggota masyarakat lainnya untuk membangun Pusat Informasi dan Layanan di tempat mereka, untuk membangun jaringan dengan masyarakat umum dan memperoleh kepercayaan dan pengalaman.

Tergantung pada pentingnya masalah dalam konteks khusus, masjid dapat memberikan prioritas pada berbagai fungsi dalam pembinaan spiritual dan religius Islam. Lembaga Islam mempekerjakan pembina/guru spiritual dan religius Muslim dengan kualifikasi sebagai berikut: (1) pemahaman yang jelas tentang Islam; (2) pengetahuan yang komprehensif tentang Alquran, Hadis, dan Fiqh; (3) kemampuan membaca Alquran sesuai dengan aturan tajwid; (4) menghafal Alquran (mereka yang mengenal Alquran dengan hati) sangat disukai; (5) penggunaan bahasa yang baik yakni bahasa Inggris dan bahasa Arab; (6) kemampuan untuk berpartisipasi dalam kegiatan antar-agama; (6) kemampuan untuk memimpin atau mengatur sholat lima waktu; (7) kemampuan untuk memimpin atau mengatur sholat pada hari Jumat, Idul Fitri, Tarawih dan Sholat Jenazah; (8) mengatur kurikulum untuk pengajaran Islam bagi semua usia; (9) mengetahui tata cara upacara perkawinan menurut shariah; (10) memberikan bimbingan agama dan melakukan kelas yang diperlukan; (11) melakukan konseling kepada pemuda, orang dewasa dan keluarga sesuai kebutuhan; (12) membantu mengumpulkan dana untuk pembangunan dan operasi masjid; (13) bertanggung jawab untuk program penjangkauan; memajukan penyebab Islam, termasuk pekerjaan $d a^{\prime} w a h$, kepada masyarakat setempat; dan (14) bersikap sopan disetiap saat (Nazila, 2011). 


\section{Pentingnya Menjaga Etika dalam Pendekatan Multikultural}

Konseling melibatkan penilaian manusia dan, sebagai konsekuensinya, konselor memiliki kewajiban untuk mendapat informasi yang baik dan harus menahan diri dari menyalahkan orang kulit hitam dan etnis lain. Konselor yang bekerja dengan klien dari berbagai budaya harus sadar bahwa salah satu aset terpenting adalah dirinya sendiri. Pengetahuan dan keterampilan, meskipun penting, sekarang selalu cukup untuk membangun dan memelihara hubungan multikultural terapeutik yang efektif. Terapis yang sensitif mengajak keluarga untuk mendidik pasien daripada menggunakan peran ahli. Ini harus membantu mencapai kolaborasi yang lebih egaliter dalam proses terapeutik. Memberikan peran ahli kepada klien juga merupakan intervensi besar dalam dirinya sendiri, sebagai cara untuk membawa masalah budaya dan etnis ke depan tanpa mengancam. Secara nyata juga, itu memberi klien peran agen terapeutik dan karena itu memberdayakan (Stephen Palmer, dkk, 1999).

Psikologi dan antropologi lintas budaya tidak pernah menikmati partership kerja yang baik. Mereka biasanya pergi dengan cara mereka sendiri. Ini karena penggunaan pendekatan yang berbeda. Para antropolog, seperti yang telah disebutkan sebelumnya, telah mempertimbangkan untuk membangun sistem sosial masyarakat yang telah mereka pelajari. Metode mereka, secara keseluruhan, secara implisit atau eksplisit menggunakan epistemologi induktivistik. Dan untuk sebagian besar, dasar teoritis dari pekerjaan mereka telah berakar pada formulasi psikoanalisis (Stephen Palmer, dkk, 1999)..

Namun permasalahan terjadi jika kita melihat dalam pandangan matrealisme. Perspektif materialis di sisi lain memandang budaya sebagai produk masyarakat. Ini menggabungkan semua aspek masyarakat, termasuk hal-hal seperti pendidikan, hukum, politik, agama dan lain-lain, serta cara hidupnya diidentifikasi didalam dan disemua kelompok. Pandangan materialistik adalah reduksionis yang mereduksi manusia menjadi aktor belaka yang memainkan bagian-bagian yang ditentukan oleh 
orang lain di masyarakat, termasuk para politisi, pemimpin gereja, guru, dll., Dan / atau oleh lingkungan, termasuk ekologi, pertumbuhan ekonomi, dan perkembangan teknologi. Penjelasan dari pandangan perspektif materialistik ala masyarakat Barat menggunakan pekerjaan sebagai alat untuk menstratifikasi orang ke dalam kelompok sosial yang berbeda. Ketergantungan pada tipologi pekerjaan yang ditetapkan, ditentukan oleh status pekerjaan, adalah semua yang biasanya dilakukan. Namun, dalam situasi dimana idealisme melebihi materialisme dan memikirkan orang-orang dari berbagai ras menjadi masalah, ada kecenderungan nyata untuk minoritas kulit hitam dan etnis yang mungkin siap bertingkat pada tingkat yang sama dengan rekan kulit putih mereka untuk secara subyektif dianggap berasal dari strata/golongan rendah. Dengan demikian diamati bahwa meskipun etnis digunakan sebagai ukuran tinggi budaya dalam konteks ras, tampak bahwa sangat sedikit perhatian diberikan kepada statusnya yang relatif rendah dalam pengukuran stratifikasi sosial dalam hal persepsi-orang (Stephen Palmer, dkk, 1999).

Oleh karena itu, klien kelompok minoritas hitam atau etnis minoritas tidak dapat diberikan kesempatan secara bebas untuk mengekspresikan diri atau perasaan mereka. Mereka mungkin tidak didengarkan atau diberi kesempatan untuk mengomentari pemahaman konselor tentang masalah dan saran selanjutnya. Risiko bagi klien adalah dia dapat menerima bantuan atau dukungan yang tidak memuaskan atau benar-benar tidak sesuai untuk situasi di mana bantuan dicari. Ini tampaknya menyiratkan bahwa konselor harus menjadi lebih lingual atau linguistik dalam penyampaian layanan konseling dalam masyarakat multikultural (Stephen Palmer, dkk, 1999).

Konselor perlu memahami budaya klien dan penggunaan bahasa dalam budaya itu untuk menjaga pentingnya dan efektifitas komunikasi mereka. Pertukaran informasi yang tidak akurat, kesalahpahaman atau salah tafsirnya juga dapat menyebabkan ketidakefektifan dalam hal hasil konseling. Terlepas dari asal-usul atau latar belakang klien, konselor perlu berkomunikasi pada tingkat pemahaman yang tepat dan mempertimbangkan apa yang harus dilakukan klien untuk merasa lebih baik atau untuk mengatasi 
masalah yang telah ditolong oleh bantuan. Perhatian juga perlu diberikan pada kesesuaian pendekatan teoritis terapeutik dan pertimbangan bagaimana teori psikologis perlu ditafsirkan dalam hal membantu populasi minoritas kulit hitam dan etnis dalam masyarakat multikultural (Stephen Palmer, dkk, 1999).

Mungkin juga ada kebutuhan bagi konselor untuk merefleksikan peran lembaga dalam mempertahankan sikap kaku yang kuat tentang etnis kulit hitam dan etnis minoritas dalam masyarakat. Pertanyaan seperti dari siapa, atau dari mana, apakah orang mendapatkan solusi mereka? bisa diatasi. Terlepas dari fokus yang jelas pada perspektif antropologis, sosiologis atau psikologis, kesadaran akan perspektif yang idealistik dan materialistis mungkin berguna bagi konselor untuk dipertimbangkan karena para konselor harus menyadari struktur stratifikasi sosial dalam masyarakat dan dampaknya terhadap hitam dan populasi etnis minoritas. Bagaimana sistem statifikasi vertikal kekuasaan dan dominasi mempengaruhi klien harus diakui dalam hal perspektif materialistik dan idealistik. Konselor perlu menyadari bahwa efek dapat menjadi penyebab dan hal ini sering dapat mengarah pada cara melegitimasi ketidaksetaraan (Stephen Palmer, dkk, 1999).

Dalam konteks perawatan Islam dalam aspek ini yakni memahami dan menghargai kepedulian Islam untuk peduli meningkatkan minat seseorang dalam mempromosikan kepedulian dalam semua aspek niat, pikiran, dan tindakan. Islam bersikeras pada pengikutnya untuk memperoleh pengetahuan dan keahlian dalam bidang usaha yang bermanfaat bagi semua makhluk hidup. Kepedulian Islam melalui praktek dan manajemen keperawatan berarti bahwa pertimbangan diberikan kepada unsur-unsur gender, kode pakaian, nilai-nilai pribadi, kode etik dan etika, persyaratan diet, keluarga berencana dan kehidupan yakni hidup yang sehat dan aman (Salleh, 1994) serta pengembangan spiritual (Rassool G.H., 2000)..

Namun, ketika seseorang mencari bantuan untuk masalah emosional atau perilaku ada harapan bahwa konselor akan memahami masalah orang itu dan akan menunjukkan beberapa kesadaran faktor budaya yang telah membentuk masalah. Ini berarti bahwa kepatuhan yang kuat terhadap pendekatan tertentu, 
meskipun mendasar untuk dipraktekkan, bukanlah hal yang perlu dilakukan konselor ketika menasihati orang dari populasi minoritas kulit hitam atau etnis. Sangat diharapkan bagi konselor untuk menyadari bahwa orang-orang dari budaya selain mereka sendiri dapat menimbulkan masalah dengan cara yang berbeda (Stephen Palmer, dkk, 1999).

Meskipun dalam setiap budaya dan masyarakat, nilai-nilai agama dan budaya penduduk pribumi memiliki dampak yang signifikan terhadap kesehatan, pendidikan dan kebijakan sosial yang mendorong perawatan kesehatan atau model perawatan yang diterima pasien. Perlu diingat bahwa populasi Muslim di seluruh dunia bukanlah entitas yang homogen. Sebaliknya, ada keragaman budaya dan adat istiadat setempat. Menurut Salleh (1994) keragaman adalah berkah dan bermanfaat bagi umat manusia jika keanekaragaman diintegrasikan ke dalam sistem yang diberikan. Mereka yang bertanggung jawab dalam sistem yang peduli harus menghormati perbedaan dan menangani sistem secara holistik. Islam mengakui perbedaan, keragaman dan toleransi diperpanjang tidak hanya bagi mereka yang tetap beriman kepada Allah tetapi juga kepada non-Muslim. Sama sekali tidak ada kontradiksi dalam menghormati dan merawat pasien non-Muslim baik di Arab Saudi atau Amerika. Ini adalah salah satu fungsi dari hukum Islam untuk melindungi status istimewa non-Muslim dan minoritas.

\section{Simpulan}

Aspek akidah, ibadah dan akhlak sangat berpengaruh pada etika dan proses umat Islam dalam menjalani kehidupan. Agama Islam telah mengatur semua hal secara detail. Semua itu termaktub dalam Alquran dan As-Sunnah. Juga, Nabi Muhammad sebagai utusan Allah untuk menyampaikan risalah kebaikan menjadi teladan bagi umat Islam. Sehingga dalam aspek sipritualitas, umat Islam terus diharapkan dapat konsisten dan terus mengasah tingkat spiritualitasnya, serta dapat menjadi imam atau pemimpin, khususnya terhadap diri sendiri dan orang lain.

Aspek iman ini menjadi kunci dalam hubungannya antara manusia dengan Tuhan, ataupun dengan sesama manusia. Hubungan sesama manusia ini tak jauh dari berbagai permasalahan, sehingga 
perlu adanya konseling atau keperawatan. Konteks keperawatan disini adalah bisa menjadi sikap serta etika dalam memberikan pelayanan keperawatan. Sehingga dengan motivasi spiritual, diharapkan para pasien konseling ataupun keperawatan dapat optimis dalam proses peyembuhannya serta bersamaan meningkatnya tingkat spiritualitas.

Selain itu pendekatan berbasis multi-kulturah menjadi solusi bagaimana memecahkan permasalahan tanpa membedakan strata sosial, ras, agama, dan lain-lain. Akibat dari perilaku rasial adalah kecenderungan inferioritas bagi liyan dan merasa superior bagi subjek. Maka ajaran Islam tentang kesetaraan dan cinta kasih dapat menjadi solusi bagi para konselor atau perawat dalam pekerjaan mereka sehari-hari. 
Islam, Etika Dan Spiritualitas: Perannya Dalam Dunia Konseling ...

\section{Daftar Pustaka}

Farnsworth, Jacob K., Kristi A. Mannon, Kenneth W. Sewell, Melissa L. Connally and Amy R. Murrell, (2016), Exploration of Caregiver Behavior on Fear of Emotion, Spirituality, and Self Compassion, Journal of Contextual Behavioral Science, http://dx.doi.org/10.1016/j.jcbs.2016.07.004

Isgandarova, Nazila, (2011), "Effective Islamic Spiritual Care: Foundations and Practices of Imams and Other Muslim Spiritual Caregivers" , Teses and Dissertations (Comprehensive), 1117.htp://scholars.wlu.ca/etd/1117

G.H., Rassool, (2000), The Crescent and Islam: Healing, Nursing and The Spiritual Dimension. Some Considerations Towards an Understanding of The Islamic Perspectives On Caring, Journal of Advanced Nursing 32(6), 1476-1484

Casarez, Rebecca L Polzer and Joan C Engebretson. (2012). Ethical Issues of Incorporating Spiritual Care Into Clinical Practice. Journal of Clinical Nursing, 21, 2099-2107, doi: 10.1111/j.13652702.2012.04168.x

van Leeuwen, Rene', (2006), Spiritual Care: Implications for Nurses Professional Responsibility, Journal of Clinical Nursing 15, 875884

Moodley, Roy, (1999), Challenges and Transformations: Counselling in a Multicultural Context, International Journal for the Advancement of Counselling 21: 139-152

Hamjah, Salasiah Hanin and Noor Shakirah Mat Akhir, (2013), Islamic Approach in Counseling, J Relig Health, DOI 10.1007/s10943013-9703-4

Palmer, Stephen, (ed.), (1999), Counselling in a Multicultural Society, (London: SAGE Publication)

Parker, Stephen, (2011), Practice Spirituality in Counseling: A Faith Development Perspective, Journal of Counseling \& Development Dover L, Van, and Pfeiffer Jb., (2007), Spiritual Care in Christian Parish Nursing. Journal of Advanced Nursing 57(2), 213-221, doi: $10.1111 / \mathrm{j} .1365-2648.2006 .04081 . x$ 